extensive work on general zoology. It is to be hoped that some of the large mass of notes that remain may be in a state capable of publication.

\section{Baron Erland Nordenskiöld}

WE regret to record the death of Baron Nils Erland Nordenskiöld, the Swedish ethnologist and explorer, which took place at Göteburg on July 5. Baron Erland Nordenskiöld, who was fifty-five years of age, was a member of a family already distinguished in the annals of exploration. He was the son of Baron Adolf Nordenskiöld, who discovered the North-East Passage, and a cousin of Prof. Otto Nordenskiolld, who led the Swedish Antarctic Expedition of 1902-3. He himself specialised in the investigation of the aboriginal cultures of America, and had travelled extensively among the native tribes, especially the less wellknown, of both Central and South America, upon whom he had for long been recognised as the first authority.

The results of Nordenskiöld's investigations were embodied mainly in a series of "Comparative Ethnographic Studies ", published in English, of which the first nine volumes, some in two parts, had appeared and others were in course of preparation. Of these, the most important was "The Copper and Bronze Ages in South America ". Yet in dealing with the origin of American cultures and the problems of diffusion, the essential quality of his mind and its strict insistence on logical proof based upon a meticulous examination of the detailed evidence were best seen in his later publications, such as vols. 8 and 9 in the series, "Modifications of Indian Culture through Inventions and Loans" and "Origin of the Indian Civilizations of South America ", the latter published in February last, in which he effectually vindicated the indigenous origin of certain important elements in Indian culture. $\mathrm{He}$ dealt with other aspects of the same problem in the Huxley Memorial Lecture delivered to the Royal Anthropological Institute in 1929, for which he received the Institute's Huxley Memorial Medal.

\section{Mr. G. H. HaLlam}

The death is announced of Mr. George Hanley Hallam, which took place at Tivoli on July 12. Mr. Hallam, who was in his eighty-sixth year, was a brilliant classical scholar. He was educated at Shrewsbury School and St. John's College, Cambridge, where he was bracketed Senior Classic in 1869, was Craven scholar, and won the Browne medals for a Greek ode twice and for a Latin ode. He was thereupon elected to a fellowship at St. John's College, and was appointed a master at Harrow in the following year. He retired in 1906.

Mr. Hallam had lived in Italy for many years and was keenly interested in the work of the British Schools of Archæology in Athens and in
Rome, keeping in close touch with the latter through his friendship with the former director, the late Dr. Thomas Ashby, and the present director, Mr. Ian Richmond. He himself had a profound knowledge of the antiquities and topography of the Roman Campagna, and was a contributor to the Journal of Roman Studies. His most recent communication to that journal dealt with the tomb of a vestal virgin discovered at Tivoli in 1930; while another discovery, also at Tivoli, a fresco found in an underground tomb, was made the subject of interpretation in a contribution dealing with the cult of Hercules. Mr. Hallam's own residence at Tivoli was itself of considerable interest to archæologists, for it was a convent erected on the site of a Roman villa, reputed to be the actual villa which was a gift from Mrcenas to the poet Horace. On excavation, however, it proved to be more extensive than had been thought, and is now generally held to be the villa of Mæcenas himself.

Mr. Hallam's continued interest in Harrow and his belief in the educative value of a knowledge of Italian and Roman culture were recently shown by the foundation of an annual prize to enable an Harrovian to spend a few weeks in Italy.

\section{Mr. Thomas Bat'a}

Thomas Bat'A, the distinguished and enlightened Czechoslovak manufacturer who met a tragic death in a flying disaster on July 12, just as he was leaving his aerodrome at Otrokovice in Moravia on a journey to Germany and England, was a leading Central European personality. From humble beginnings he built up one of the largest and most progressive leather goods concerns in the world. Through hard work, skill, and a thorough knowledge of all the details of the industry, he evolved the model establishment at Zlin, which has grown tenfold since the War, in order to accommodate his ever expanding undertakings. He was also responsible for the new educational buildings for the young and adult employees, and also for the up-to-date hospital and clinics which were at the disposal of townsfolk and others. Whilst he expected his workers to give their best service, he studied their interest in every way. He limited their duties to five days a week and encouraged them to improve their knowledge in their leisure, and anyone who showed ability or initiative obtained rapid promotion. He believed in strict discipline, but never expected anything from a worker that he was not prepared to accept himself.

Although Mr. Bat'a's energies seemed to be wholly devoted to industry, he found time for cultural pursuits and was an expert linguist. Czechoslovak educational and scientific institutes frequently received handsome donations from $\mathrm{Mr}$ Bat'a, and he provided funds for the excavations in Moravia which, a few years ago, revealed relics of a prehistoric settlement. Mr. Bat'a was fiftysix years of age. 